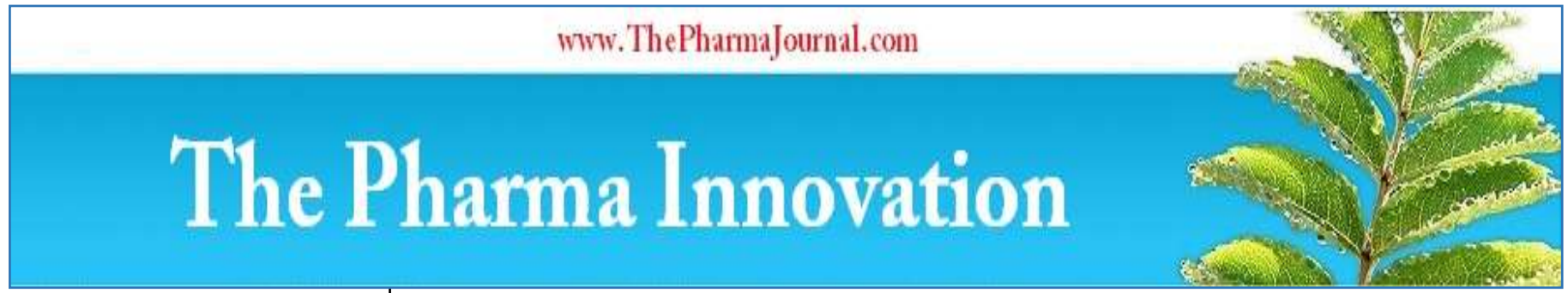

ISSN (E): 2277- 7695

ISSN (P): 2349-8242

NAAS Rating: $\mathbf{5 . 2 3}$

TPI 2021; 10(4): 689-692

(C) 2021 TPI

www.thepharmajournal.com

Received: 24-02-2021

Accepted: 26-03-202

Deepak G Joshi

Research Scholar, Shri

Jagdishprasad Jhabarmal

Tibrewala University,

Rajasthan, India

Dr. Rakesh Kumar Jat

Principal, Department of

Pharmacy, Shri Jagdishprasad

Jhabarmal Tibrewala

University, Rajasthan, India

Dr. Sandeep B Patil

Associate Professor,Adarsh

College of Pharmacy, Vita,

Sangli, Maharashtra, India
Corresponding Author: Deepak G Joshi

Research Scholar, Shri

Jagdishprasad Jhabarmal

Tibrewala University,

Rajasthan, India

\section{In vitro protein denaturation and membrane stabilizing anti-arthritic activity of aqueous extracts of bark of Ficus benghalensis L. against methotrexate}

\author{
Deepak G Joshi, Dr. Rakesh Kumar Jat and Dr. Sandeep B Patil
}

DOI: https://doi.org/10.22271/tpi.2021.v10.i4j.6038

\begin{abstract}
The in vitro anti-arthritic activity of the aqueous extract of bark of Ficus benghalensis L. were studied by protein denaturation inhibition assay and membrane stabilizing activity. Methotrexate, well-established and promising DMARDs which is commonly used in inflammatory conditions like rheumatoid arthritis was used as standard drug .In rheumatoid arthritis protein denaturation was the main cause of inflammation. HRBC membrane stabilization was similar to lysosomal membrane which influences the process of inflammation. The percentage of protein denaturation and membrane stabilization for aqueous extracts were done at different concentrations $(100,200,400,800,1000 \mu \mathrm{g} / \mathrm{ml})$. The maximum inhibition of protein denaturation and membrane stabilization of aqueous extracts of Ficus benghalensis L. was found to be $45.31 \pm 1.90$ and $62.50 \pm 0.66$ at dose of $1000 \mu \mathrm{g} / \mathrm{ml}$ respectively and standard inhibition of protein denaturation and membrane stabilization using methotrexate was found to be 87.50 and 81.25 at 100 $\mu \mathrm{g} / \mathrm{ml}$ respectively. The aqueous extracts of Ficus benghalensis showed significant activity at the highest concentration.
\end{abstract}

Keywords: Ficus benghalensis, protein denaturation assay, membrane stabilizing activity, anti-artrhtic activity, methotrexate

\section{Introduction}

Inflammation is the defense mechanism in living tissues to get protection from injury, irritation and infection. The mechanism of inflammation is attributed in part to release of reactive oxygen species (ROS) from activated neutrophils and macrophages. Prolonged inflammation leads to rheumatoid arthritis, autoimmune disease and other infectious diseases [1].

Rheumatoid arthritis is a common chronic inflammatory autoimmune disease of joints accompanied by progressive destruction of bones, joints and affects other organs of body. It affects an estimated $1 \%$ population throughout the world. The cause of rheumatic arthritis is due to genetic and environmental factors which results in body's immune system attacks the joints [2, 3]. Progression of the disease results in joint destruction, deformity and significant disability [4] .It is characterized by autoantibody production, bone destruction, skeletal disorders and synovial inflammation ${ }^{[5]}$.

Various classes of drugs which have been used to treat pain and inflammation in rheumatoid arthritis belong to the category of NSAIDs, Corticosteroids, DMARDs and Biological. All these drugs show severe side effects like ulceration, malignancies and infections ${ }^{[6]}$. Therefore, there is need to find new effective, economical, beneficial and safe alternative treatment for rheumatoid arthritis. The traditional plants used worldwide remains major source of active constituents for curing various diseases. World's most population relies on traditional medicine for primary healthcare needs and involves use of plant extracts or their components. The traditional medicine remains an alternative to modern medicine. The combination therapies of herbal products with DMARDS are gradually and widely accepted in management of rheumatoid arthritis. Various plants have been used for curing pain and inflammatory conditions like arthritis. Plants are excellent sources of antioxidants, anti-arthritic and antiinflammatory agents ${ }^{[7]}$.

Proteins lose its structure or become denatured when there is activation of various enzymes, migration of tissues and break down of tissues occurs ${ }^{[8,9]}$. The hypo tonicity and heat induced hemolysis of erythrocytes is commonly used method for assessing anti-inflammatory activity. 
The erythrocyte membrane resembles to lysosomal membrane and as such, the effect of drugs on the stabilization of erythrocyte could be extrapolated to the stabilization of lysosomal membrane. In addition, lysis of lysosomal membranes during chronic inflammation has been proven to release pro-inflammatory markers including activated neutrophils, proteases and histamines at the local site of tissue damage ${ }^{[10,11,12]}$.

Ficus benghalensis L. commonly known as Banyan tree belongs to family Moraceae. Various parts of plants is claimed to possess anti-arthritic, antileprotic, antiinflammatory, anti-spasmodic, laxative properties and useful in many other disease ${ }^{[13,14]}$. In ayurveda it is used for diarrhoea, dysentery, piles, and diuretic, astringent and applied to gums to lessen inflammation. The various activities like antioxidant property ${ }^{[15]}$, immunomodulatory activity of methanolic extract of roots ${ }^{[16]}$ and anti-inflammatory activity of ethanolic bark extract ${ }^{[17]}$ have been reported. The analgesic, anti-rheumatic and anti-oxidant activity of methanolic extract were studied at doses of 100,200, and 3000 $\mathrm{mg} / \mathrm{kg}{ }^{[18]}$.

The present study is aimed to investigate anti-arthritic activity of aqueous extract of Ficus benghalensis L.by in vitro methods using methotrexate as a standard drug.

\section{Material and Method \\ Collection of Plant}

The barks of Ficus benghalensis L. were collected from local area of Sangli districts and authenticated by Dr. V. B. Awale, an approved Botanist, Dept. of Botany, Dr. Patangrao kadam Mahavidyalaya, Sangli. A specimen voucher no. (ACOP/SNG/101 to 120) has been stored for further reference in Department of Pharmacognosy, Adarsh College of Pharmacy, Vita, Sangli, MS, India.

\section{Extraction}

The cleaned barks of Ficus bengalensis L. were dried at room temperature. Further it was pulverized and passed through sieve no.40.The obtained powdered material were then macerated for 7 days with water containing chloroform in the ratio 16:1. The filtered extract was concentrated and stored for further use.

\section{Method: In vitro anti -arthritic activity ${ }^{[19,20]}$}

The anti-denaturation study for investigating anti-arthritic activity was performed using bovine serum albumin (BSA).When BSA is heated, it undergoes denaturation and antigens are expressed which are associated with type-III hypersensitivity reaction, which in turn is related to various diseases like rheumatoid arthritis.

\section{Inhibition of protein denaturation ${ }^{[21]}$}

The method was adopted from the previous article published by Pavithra, T.K et al. 2015 with slight modification. The reaction mixture consisted of the $100 \mu \mathrm{l}$ aqueous extracts of Ficus benghalensis (final concentration 100, 200, 400, 800, $1000 \mu \mathrm{g} / \mathrm{ml}$ ) and $100 \mu \mathrm{l}$ of $5 \%$ aqueous solution of bovine serum albumin (BSA). The sample was incubated at $37^{\circ} \mathrm{C}$ for $20 \mathrm{~min}$ and then temperature. Was increased to $70{ }^{\circ} \mathrm{C}$ in hot water bath for $10 \mathrm{~min}$.

The mixture was allowed to cool under tap water for $10 \mathrm{~min}$ after which turbidity and absorbance was measured at 660 nm. The blank comprised of the distilled water. The results were compared with methotrexate.
Formula: Formula: The percentage inhibition of protein denaturation can be calculated as:

$$
\text { Percentage inhibition }=\frac{\text { Abs control }- \text { Abs sample }}{\text { Abs control }} \times 100
$$

\section{Effect on Membrane Stabilization ${ }^{\text {[2] }}$}

The method used was from procedure adopted by Vallabh Deshpande et al. with some modifications. Blood sample from healthy human volunteers who did not consumed NSAID for two weeks prior to this experiment was obtained. The reaction mixtures $4.5 \mathrm{ml}$ consists of $2 \mathrm{ml}$ hypotonic saline $(0.25 \% \mathrm{NaCl})+1 \mathrm{ml} 0.15 \mathrm{M}$ phosphate buffer $(\mathrm{pH} 7.4)+1 \mathrm{ml}$ test solution $(100-500 \mu \mathrm{g} / \mathrm{ml})$ in normal saline $+0.5 \mathrm{ml}$ of $10 \%$ $\mathrm{HRBC}$ in normal saline. The mixture was incubated at $56 \mathrm{oC}$ for 30 minutes. The test tubes were cooled under running tap water for 20 minutes. After that reaction mixture was centrifuged for 3000rpm for 10min and the absorbance of the supernatant was measured at $560 \mathrm{~nm}$. The methotrexate was used as standard drug.

Formula: The percentage membrane stabilization activity was calculated as per following formula

$\%$ protection $=\frac{100-\text { OD of sample }}{\text { OD of control }} \times 100$

Table 1: The percentage inhibition of different concentration of aqueous extracts of Ficus benghalensis L. by Protein denaturation method (BSA)

\begin{tabular}{|c|c|c|c|c|}
\hline Plant name & Conc $(\boldsymbol{\mu g} / \mathbf{m l})$ & OD & $\begin{array}{c}\text { \% } \\
\text { inhibition }\end{array}$ & \multirow{2}{*}{ IC50 } \\
\hline Blank & & 0.64 & & \\
\hline Ficus benghalensis & 100 & 0.57 & $10.94 \pm 0.80$ & \\
& 200 & 0.53 & $17.19 \pm 1.03$ & \multirow{2}{*}{1157.68} \\
\hline & 400 & 0.47 & $26.56 \pm 1.14$ & \\
\cline { 1 - 4 } & 800 & 0.41 & $35.94 \pm 1.06$ & \\
\cline { 1 - 4 } & 1000 & 0.352 & $45.31 \pm 1.90$ & \\
\hline
\end{tabular}

Values represent in the results are mean \pm SD of three replicates; linear regression analysis was used to calculate IC50 value

Table 2: The percentage inhibition of different concentration of Methotrexate by Protein denaturation method (BSA)

\begin{tabular}{|c|c|c|c|c|}
\hline Drug & $\begin{array}{c}\text { Conc } \\
(\mu \mathrm{g} / \mathrm{ml})\end{array}$ & OD & $\begin{array}{c}\% \\
\text { inhibition }\end{array}$ & $\begin{array}{c}\text { IC50 } \\
(\mu \mathrm{g} / \mathrm{ml})\end{array}$ \\
\hline Blank & & 0.64 & & \\
\hline Standard Methotrexate & 10 & 0.48 & 25.00 & \multirow{5}{*}{35.53} \\
\hline & 20 & 0.31 & 51.56 & \\
\hline & 40 & 0.29 & 54.68 & \\
\hline & 80 & 0.17 & 73.43 & \\
\hline & 100 & 0.08 & 87.50 & \\
\hline
\end{tabular}

Values represent in the results are mean $\pm \mathrm{SD}$ of three replicates; linear regression analysis was used to calculate IC50 value

Table 3: The percentage stabilization of aqueous extracts of Ficus benghalensis by HRBC Membrane Stabilization method.

\begin{tabular}{|c|c|c|c|c|}
\hline Plant name & Conc $(\boldsymbol{\mu g} / \mathbf{m l})$ & OD & \% inhibition & IC50 \\
\hline Blank & & 0.32 & & \\
\cline { 1 - 4 } Ficus benghalensis & 100 & 0.23 & $28.12 \pm 1.01$ & \\
\cline { 1 - 4 } & 200 & 0.21 & $34.37 \pm 1.19$ & \multirow{3}{*}{747.50} \\
\hline & 400 & 0.19 & $40.62 \pm 1.10$ & \\
\hline & 800 & 0.17 & $46.87 \pm 0.93$ & \\
\cline { 1 - 3 } & 1000 & 0.12 & $62.50 \pm 0.66$ & \\
\hline
\end{tabular}

Values represent in the results are mean \pm SD of three replicates; linear regression analysis was used to calculate IC50 value 
Table 4: The percentage inhibition of different concentration of Methotrexate by HRBC Membrane Stabilization method.

\begin{tabular}{|c|c|c|c|c|}
\hline Drug & $\begin{array}{c}\text { Conc } \\
(\boldsymbol{\mu g} / \mathbf{m l})\end{array}$ & OD & \% inhibition & $\begin{array}{c}\text { IC50 } \\
(\boldsymbol{\mu g} / \mathbf{m l} \mathbf{l})\end{array}$ \\
\hline Blank & & 0.32 & & \\
\cline { 1 - 4 } Standard (methotrexate) & 10 & 0.15 & 53.12 & \\
\hline & 20 & 0.12 & 62.50 & \multirow{2}{*}{$>100$} \\
\cline { 1 - 4 } & 40 & 0.10 & 68.75 & \\
\hline & 80 & 0.08 & 75.00 & \\
\hline & 100 & 0.06 & 81.25 & \\
\cline { 1 - 3 } & &
\end{tabular}

Values represent in the results are mean \pm SD of three replicates; linear regression analysis was used to calculate IC50 value

\section{Results and Discussion}

The in vitro anti-arthritic activity of various concentrations of aqueous extract of bark of Ficus benghalensis L. was studied by protein denaturation and HRBC membrane stabilization method respectively. The inhibition of protein denaturation and inhibition of hypotonicity induced membrane stabilization was taken as a measure of the anti-arthritic activity. The percentage of inhibition of protein denaturation and percentage of membrane stabilization for aqueous extract of Ficus benghalensis and methotrexate were done at concentration $(100,200,400,800,1000 \mu \mathrm{g} / \mathrm{ml})$ and $(10,20$, $40,80,100 \mu \mathrm{g} / \mathrm{ml}$ ) respectively. Aqueous extracts of Ficus benghalensis are effective in inhibiting protein denaturation at different concentrations. It showed that maximum inhibition $65.62 \% \pm 1.10$ at $1000 \mu \mathrm{g} / \mathrm{ml}$ of aqueous extract and $87.50 \%$ at $100 \mu \mathrm{g} / \mathrm{ml}$ of methotrexate. The inhibition of hypotonicity induced HRBC membrane lysis i.e., stabilization of HRBC membrane was taken as a measure of the anti-arthritic activity. Aqueous extracts of Ficus benghalensis are effective in inhibiting the heat indued hemolysis of HRBC at different concentrations. It showed that maximum inhibition 71.87 \pm 1.46 at $1000 \mu \mathrm{g} / \mathrm{ml}$ of aq. extract and $81.25 \%$ at $100 \mu \mathrm{g} / \mathrm{ml}$ of methotrexate. With increasing 'concentration, the inhibition of protein denaturation and membrane stabilization and protection is also increased. Hence anti-arthritic activity of extracts was concentration dependent.

Protein denaturation which is identified as a cause of inflammation occurs when living tissue is injured. Due to this disruption of electrostatic, hydrogen, disulphide bonds occurs which results in denaturation of proteins. The compounds which prevent these changes are having potential anti-arthritic activity. HRBC membrane stabilization was similar to lysosomal membrane which influences the process of inflammation. The inflammatory response of lysosomal membrane was important because it helps the inhibition process by inhibiting the release of lysosomal constituents of activated neutrophil. The aqueous extract of Ficus benghalensis may possibly inhibit the release of lysosomal content of neutrophils at the site of inflammation.

\section{Conclusion}

Present research work was an attempt to find out the ant arthritic potential of aqueous extract of bark of Ficus benghalensis L. Protein denaturation and Stabilization of HRBC membrane by hypotonicity induced membrane lysis was carried out to check activities. Our present work on in vitro studies of Ficus bengalensis demonstrate significant and dose dependent ant arthritic activity. The presence of active principles in the aqueous extracts may be responsible for this activity. Further investigation should be carried out to find mechanism of action of aqueous extract of Ficus benghalensis L.

\section{References}

1. Rahman H, Eswaraiah MC, Dutta AM. In-vitro antiinflammatory and anti-arthritic activity of Oryza sativa, Am-euras, J Agric Environ Sci 2015;15;115-21.

2. Kumari CS, Yasmin N, Hussain MN, Babuselvam M. In vitro anti-inflammatory and anti-arthritic property of rhizopora. Int J Pharm Sci Res 2015;6:3

3. Pant K, Kshitij A, Prem S. To study in vitro antiinflammatory activity of Antrocephalus cadamba leaves extract, Int j Pharm sci 2012;3;55-60.

4. Geetha DH, Jayashree I, Rajeswari M. In vitro antiarthritic activity of Elaeocarpus serratus Linn. (Elaeocarpaceae), Int $\mathrm{J}$ Pharm Sci Res (IJPSR) 2015;5;62649-51.

5. Iain B McInnes, Georg Schett. The pathogenesis of rheumatoid arthritis. Engl J Med 2011;365;2205-19

6. Reddy VJS, Rao PGD, Lakshmi GR. A review on antiarthritic activity of some medicinal plants.J Glob trends Pharm Sci 2014;5:2061-73.

7. Atawodi SE, Yakubu OE, Umar IA. Antioxident and hepatoprotective effects of Parinari curatellifolia root., Int J Agriculture Biol 2013;15:523-528.

8. Dharsana JN, Mathew SM. Preliminary screening of antiinflammatory and antioxidant activity of Morianda umbellate. Int. J. Pharm. life Sci 2013;5(8),2014,37743779.

9. Kandikattu K, Bharath RKP, Sunil PR, Ranjit KK, Singh BR. Evaluation of anti-inflammatory activity of Canthium parviflorum by in-vitro method .Indian J. Res. pharm. Biotech 2013;1(5):729-730S.

10. Anosike CA, Obidoa O, Ezeanyika LU. Membrane stabilization as a mechanism of the anti-inflammatory activity of methanol extract of garden egg (Solanum aethiopicum). Daru 2012;20:76.

11. Boniface PK, Verma S, Shukla A. et al. Membrane stabilisation: a possible anti-inflammatory mechanism for the extracts and compounds from Spathodea campanulata. Nat Prod Res 2014;28:2203-7.

12. Debnath PC, Das A, Islam A, et al. Membrane stabilization - A possible mechanism of action for the anti-inflammatory activity of a Bangladeshi medicinal plant: Erioglossum rubiginosum (Bara Harina). Pharmacogn J 2013;5:104-107.

13. Kirtikar KR, Basu BD. Indian Medicinal Plants, International Book Distributors, Deharadun 2008;3:19371940.

14. Sharma PC, Yelne MB, Dennis TJ. Database on medicinal plants used in Ayurveda, Vol.3.,CCRAS Publication,Reprint Edition, New Delhi 2005, 450-471.

15. Rimi Shulka, Shweta Gupta. Antioxident effects of aqueous extract of bark of Ficus bengalensis. J. of Ethanopharmacolgy 2004;92(1):47-51.

16. Gabhe SY, Tatke PA, Khan TA. Evaluation of immunomodulatory activity of Ficus bengalensis. Ind. J. Pharmacology 2006;38(4):271-275.

17. Patil VV, Pimpirikar RB. Pharmacognostic studies and evaluation of anti-inflammatory activity of Ficus benghalensis. Journal Young Pharmacists 2009;1:49-53.

18. Manocha N, Chandra SK, Sharma V, Sangameswaran B. Anti-rheumatic and antioxidant activity of extract of stem bark of Ficus bengalensis. Research J.of Chemical Sciences 2011;1(2);2-8.

19. Mohamed M, Shabi Subashini Utharpathy, Chellappan David Raj, Gayathri Krishnamoorthy. Analgesic and 
Anti-arthritic effects of Enicostemma hittorale Blume, Advances in Bioscience and Biotechnology 2014;5:10181024

20. Saket SS, Juvekar AR, Gambhire MN. In-vitro antioxidant and anti-inflammatory activity of methanol extract of Oxalis corniculate L. Int $\mathrm{J}$ Pharm Sci 2010;2:146-155.

21. Pavithra TK, Smitha KP, Kulashekar KS, Ashok Kumar BS. Evalation of invitro Anti-Arthritic Activity of Vitex negundo against the Denaturation of Protein, Int. J. Curr. Micribiol, App. Sci 2015;4(9):87-90.

22. Vallabh Deshpande, Varsha Jadhav M, Kadam VJ. in vitro anti-arthritic activity of Abutilam indicum (Linn,),J Pharm Res 2009;2(4):644-645.

23. Sangeetha G, Vidhya R. In vitro anti-inflammatory activity of different parts of Pedalium murex (L.). Int J Herb Med 2016;4(3):31-6.

24. Ikwegbue PC, Masamba P, Oyinloye BE, Kappo AP. Roles of heat shock proteins in apoptosis, oxidative stress, human inflammatory diseases, and cancer. Pharmaceuticals 2018;11(2):E2. https://doi.org/10.3390/ph11010002.

25. Labu ZK, Laboni FR, Tarafdar M, Howlader MSI, Rashid MH. Membrane stabilization as a mechanism of anti-inflammatory and thrombolytic activities of ethanolic extract of arial parts of Spondiasis pinanata (family: Anacardiaceae). Pharmacology online 2015;2:44-51.

26. Ranasinghe $\mathrm{P}$, Ranasinghe $\mathrm{P}$, Abeysekera WP, Premakumara GA, Perera YS, Gurugama $\mathrm{P}$, et al. In vitro erythrocyte membrane stabilization properties of Carica papaya L. leaf extracts. Pharm Res 2012;4(4):196-202. https://doi.org/10.4103/0974-8490.102261. 